E-JURNAL EKONOMI DAN BISNIS UNIVERSITAS UDAYANA
Available online at https://ojs.unud.ac.id/index.php/EEB/index
Vol. 10 No. 7, July 2021, pages: 612-625
e-ISSN: 2337-3067

\title{
PENGARUH NET INTEREST MARGIN, NON PERFORMING LOAN, DAN CAPITAL ADEQUACY RATIO TERHADAP HARGA SAHAM
}

\section{Sayid Aulia Taslim ${ }^{1}$ Gusganda Suria Manda ${ }^{2}$}

Article history:

Submitted: 25 Januari 2021

Revised: 18 Maret 2021

Accepted: 11 April 2021

\section{Keywords:}

Net Interest Margin;

Non Performing Loan;

Capital Adequacy Ratio;

Stock Prices

\section{Kata Kunci:}

Net Interest Margin;

Non Performing Loan;

Capital Adequacy Ratio;

Harga Saham

\section{Koresponding:}

Universitas Singaperbangsa

Karawang, Jawa Barat,

Indonesial

Email:sayidauliaa@gmail.com ${ }^{1}$

\section{Abstract}

The purpose of this study was to determine the effect of Net Interest Margin (NIM), Non Performing Loan (NPL), and Capital Adequacy Ratio (CAR) partially and simultaneously against stock prices in conventional commercial banks listed on the Indonesia Stock Exchange in 2015-2019. This study was a quantitative approach where the data source was from the financial statements of banking companies that have been published. The sampling technique was purposive sampling and obtained 15 banking companies. The data were analyzed by linear regression using SPSS 25 where previously performed classical assumption test that includes normality test, multicollinearity test, autocorrelation test, and heteroscedasticity test with level significance 5\%. The results of partial between NIM and CAR on stock prices shows that the NIM and CAR have a positive and significant effect on stock prices. Whereas the results of partial between NPL on stock prices shows that the NPL has a negative and significant effect on stock prices. The simultaneous test results of the NIM, $N P L$, and CAR have a significant effect on stock prices. The contribution of NIM, NPL, and CAR simultaneously to stock prices was 20,9\% and the remaining $79,1 \%$ was influenced by other variables not examined.

\begin{tabular}{l} 
Abstrak \\
Tujuan penelitian ini untuk mengetahui pengaruh Net Interest \\
\hline Margin (NIM), Non Performing Loan (NPL), dan Capital Adequacy Ratio \\
(CAR) secara parsial dan simultan terhadap harga saham pada Bank Umum \\
konvensional yang terdaftar di Bursa Efek Indonesia tahun 2015-2019. \\
Penelitian ini menggunakan pendekatan kuantitatif dimana data bersumber \\
dari laporan keuangan perusahaan perbankan yang telah dipublikasi. Data \\
penelitian menggunakan data sampel dengan purposive sampling dan \\
diperoleh sebanyak 15 perusahaan perbankan. Analisis data menggunakan \\
analisis regresi linear dengan software SPSS 25 dimana sebelumnya \\
dilakukan uji asumsi klasik yang meliputi uji normalitas, uji \\
multikolinearitas, uji autokorelasi, dan uji heteroskedastisitas dengan taraf \\
signifikansi 5\%. Hasil pengujian parsial antara NIM dan CAR terhadap \\
harga saham menunjukkan bahwa NIM dan CAR berpengaruh positif dan \\
signifikan terhadap harga saham. Sedangkan hasil pengujian parsial antara \\
NPL terhadap harga saham menunjukkan bahwa NPL berpengaruh negatif \\
dan signifikan terhadap harga saham. Hasil pengujian simultan variabel \\
NIM, NPL, dan CAR berpengaruh signifikan terhadap harga saham. \\
Kontribusi variabel NIM, NPL, dan CAR secara simultan terhadap harga \\
saham sebesar 20,9\% dan sisanya $79,1 \%$ dipengaruhi variabel lain yang \\
tidak diteliti.
\end{tabular}

Universitas Singaperbanga Karawang, Jawa Barat, Indonesia ${ }^{2}$

Email: gusganda.suriamanda@fe.unsika.ac.id 


\section{PENDAHULUAN}

Salah satu parameter keberhasilan dalam mengelola suatu perusahaan adalah harga saham. Harga saham merupakan suatu cerminan keberhasilan atas keputusan keuangan perusahaan yang strategis, seperti dalam hal pendanaan, investasi, dan dividen. Pasar akan merespon hal tersebut melalui perdagangan saham di pasar modal. Perubahan harga saham merupakan respon dari aktivitas pasar dan perbankan (Setyawan \& Mawardi, 2012).

Adanya kekuatan di dalam mekanisme pasar (penawaran dan permintaan) yang berlangsung secara terus menerus di bursa efek dapat menimbulkan harga saham berfluktuatif. Perubahan yang terjadi pada harga saham dapat memberikan indikasi terkait kegairahan dan kelesuan kegiatan pasar modal serta pemodal dalam melakukan transaksi jual beli saham (Cahyani \& Putri, 2018). Semakin banyak investor yang membeli saham pada suatu perusahaan maka harga saham perusahaan tersebut akan meningkat. Begitu pula sebaliknya, apabila semakin banyak investor yang ingin menjual atau menerbitkan saham tersebut maka harga saham akan menurun (Martanorika, 2018).

Informasi yang beredar di pasar seringkali langsung direspon oleh investor, sehingga mempercepat respon pasar terhadap informasi yang validitasnya tidak dapat dipastikan. Beberapa tahun lalu harga saham sektor perbankan turun karena adanya rumor mengenai pembatasan margin bunga (net interest margin) yang disebabkan oleh kepanikan investor. Keuntungan bank cenderung turun dari tahun sebelumnya seiring dengan adanya pembatasan net interest margin. Otoritas Jasa Keuangan (OJK) tidak akan membatasi pendapatan bunga bersih bank, tetapi akan menurunkan bunga kredit menjadi single digit meningkatkan pertumbuhan kredit negara (Infobanknews, 2016).

Sudut pandang dari pemegang saham mengenai aspek-aspek yang mempengaruhi fluktuasinya harga saham dibagi menjadi tiga kategori, yakni aspek fundamental, aspek teknis, dan aspek sosial, ekonomi, politik. Aspek-aspek tersebut secara simultan akan membentuk kekuatan pasar dan mempengaruhi transaksi di dalam perusahaan yang pada akhinya harga pasar saham perusahaan akan mengalami berbagai macam profitabilitas terkait naik turunnya harga saham (Takarini \& Hendrarini, 2011).

Aspek fundamental merupakan aspek yang sangat menentukan fluktuasinya harga saham. Aspek tersebut yang memberikan gambaran bersifat analitis dan eksplisit bagi para shareholder atas realisasi dalam mengelola perusahaan oleh pihak manajemen perusahaan. Aspek fundamental pada umumnya adalah rasio-rasio keuangan yang digunakan untuk menganalisis dan menilai kinerja perusahaan. Pada dasarnya terdapat tiga rasio yang harus diamati dalam menilai kinerja perusahaan perbankan, seperti Net Interest Margin (NIM), Non Performing Loan (NPL), dan Capital Adequacy Ratio (CAR).

Net interest margin adalah indikator yang diperlukan untuk mengukur kemampuan manajemen bank dalam mengelola aset produktif, khususnya dalam menghasilkan laba bersih. Informasi mengenai kemampuan perusahaan guna menghasilkan laba dalam kurun waktu tertentu tentunya merupakan suatu hal yang sangat menarik bagi para stakeholder. Interpretasi terhadap informasi kemampuan laba perusahaan dapat memberikan pemahaman yang lebih baik serta lebih dalam terkait kinerja keuangan suatu perusahaan. Hal ini merupakan dasar untuk memprediksi posisi keuangan perusahaan serta kinerja perusahaan di masa yang akan datang. Faktor yang mempengaruhi besar kecilnya net interest margin salah satunya adalah penurunan bunga deposito perbankan dibandingkan bunga kredit. Faktor lain yang mempengaruhi net interest margin adalah perbaikan rating investasi Indonesia. Selain itu, kondisi likuiditas perbankan juga dapat mempengaruhi net interest margin. 
Rasio fundamental lain yang harus diperhatikan investor dalam berinvestasi adalah non performing loan. Non Performing Loan (NPL) atau tingkat kredit bermasalah merupakan indikator yang dapat memberikan penilaian terkait kinerja fungsi bank. Semakin tinggi tingkat kredit bermasalah maka menunjukkan bahwa bank tidak dapat mengelola usahanya, seperti masalah likuiditas (tidak mampu untuk membayar pihak ketiga), profitabilitas (utang tak tertagih), dan solvabilitas (penurunan modal). Penurunan laba merupakan salah satu dampaknya, karena bank justru akan kehilangan sumber pendapatannya selain harus mencadangkan sesuai kolektibilitas kredit (Diyanti \& Widyarti, 2012). Sesuai yang ditetapkan oleh Bank Indonesia dalam Surat Edaran No. 6/23/DPNP Tahun (2004), bahwa kriteria bank dinyatakan sehat memiliki tingkat NPL tidak melebihi dari 5\% atau sama dengan 5\%. Tingginya tingkat NPL akan berdampak pada penurunan laba yang diterima oleh bank. Tingkat laba merupakan salah satu proyeksi dari performa atau kinerja suatu perusahaan yang menjadi acuan bagi investor maupun analisis fundamental dalam mengkaji saham perusahaan. Sehingga, apabila terjadinya penurunan laba di suatu perusahaan maka mengakibatkan turunnya harga saham.

Peranan modal dalam perusahaan tidak hanya dimanfaatkan untuk kepentingan pengembangan usaha, melainkan juga dimanfaatkan sebagai penyangga (buffer) untuk menyerap kerugian kegiatan usaha (Cahyani \& Putri, 2018). Besarnya modal suatu bank akan mempengaruhi efektif atau tidaknya bank dalam menjalankan aktivitasnya dan dapat mempengaruhi kepercayaan masyarakat (peminjam) terhadap kinerja bank (Puspitasari, 2009). Menurut Peraturan OJK No.11/PJOK.03 tahun (2016) tentang Kewajiban Penyediaan Modal Minimum Bank Umum menyatakan bahwa setiap bank diwajibkan untuk menyediakan modal minimum sesuai profil risiko bank tersebut. Penyediaan modal minimum dapat diukur dengan menggunakan Capital Adequacy Ratio (CAR). Semakin tinggi nilai CAR maka semakin baik bank dalam mempertahankan kecukupan modalnya untuk menjaga kesehatan kualitas bank (Winarsih, 2016).

Penelitian mengenai pengaruh rasio keuangan khususnya rasio net interest margin, rasio non performing loan, dan rasio capital adequacy ratio terhadap perubahan harga saham perbankan terus mengalami perkembangan dan semakin dinamisnya pergerakan dunia perbankan saat ini, menimbulkan munculnya beberapa kebijakan-kebijakan baru yang disesuaikan dengan keadaan perekonomian Indonesia. Berdasarkan hal tersebut, maka tujuan dari penelitian ini adalah untuk menguji pengaruh net interest margin, non performing loan, dan capital adequacy ratio terhadap harga saham bank umum konvensional yang terdaftar di Bursa Efek Indonesia.

Aktivitas perbankan yang semakin kompleks menuntut bank agar meningkatkan penerapan manajemen risiko. Pengelolaan manajemen risiko sangat penting karena mengindikasikan kualitas manajemen perusahaan itu sendiri (Hendrayana \& Yasa, 2015). Pemahaman terkait hubungan antara tingkat keuntungan dan risiko dalam berinvestasi merupakan dasar dalam pengambilan keputusan investasi bagi setiap investor. Dengan menerapkan manajemen risiko, bank dapat melaksanakan seluruh aktivitas bisnis secara terintergrasi dalam sistem manajemen risiko yang akurat dan komprehensif untuk mengurangi dampak risiko pada setiap aktivitas bank (Cahyani \& Putri, 2018).

Penelitian mengenai variabel net interest margin dilakukan oleh (Catriwati, 2017; Larasati et al., 2017; Wulansari \& Prihantoro, 2018) yang menyatakan bahwa secara parsial net interest margin berpengaruh positif dan signifikan terhadap harga saham. Pernyataan tersebut menunjukkan bahwa setiap kenaikan net interest margin akan menyebabkan kenaikan pada harga saham. Perubahan pada net interest margin mengacu pada kualitas kredit yang diberikan oleh bank. Kualitas kredit yang baik mampu membuat pendapatan bunga bersih meningkat, sehingga mempengaruhi keuntungan bank yang pada akhirnya akan meningkatkan profitablitas perusahaan. Hal tersebut akan menambah tingkat 
kepercayaan masyarakat terhadap kinerja bank, sehingga harga saham akan mengalami kenaikan. Dengan demikian, pengaruh net interest margin terhadap kinerja bank akan berdampak positif terhadap harga saham. Sementara hasil penelitian yang dilakukan oleh Hajar et al. (2020) menyatakan bahwa secara parsial net interest margin berpengaruh negatif terhadap harga saham. Namun, terdapat hasil penelitian yang berbeda, yaitu penelitian yang dilakukan oleh (Medyawicesar, 2018; Nureny, 2020) yang menyatakan bahwa secara parsial net interest margin tidak berpengaruh terhadap harga saham. Berdasarkan pemaparan tersebut, maka hipotesis alternatif pertama yang diajukan dalam penelitian ini adalah: $\mathrm{H}_{1}$ : Net Interest Margin (NIM) berpengaruh positif dan signifikan terhadap harga saham.

Penelitian mengenai variabel non performing loan dilakukan oleh (Buchory, 2020; Martanorika, 2018) yang menyatakan bahwa secara parsial non performing loan berpengaruh negatif dan signifikan terhadap harga saham. Pernyataan tersebut menunjukkan bahwa setiap kenaikan non performing loan menyebabkan penurunan pada harga saham dan sebaliknya, jika terjadi penurunan non performing loan maka akan menyebabkan kenaikan pada harga saham. Terjadinya kenaikan pada non performing loan mengakibatkan tidak tercakupinya cadangan Penyisihan Penghapusan Aktiva Produktif (PPAP), sehingga penghambatan kredit harus diperhitungkan sebagai beban biaya yang berpengaruh pada keuntungan bank (Martanorika, 2018). Tingkat non performing loan mencerminkan baik tidaknya kinerja suatu perbankan. Semakin tinggi tingkat non performing loan maka risiko yang ditanggung pihak bank sedang tidak baik. Hal ini akan mempengaruhi keputusan investor dalam berinvestasi sehingga non performing loan akan mempengaruhi harga saham. Sementara hasil penelitian yang dilakukan oleh (Harahap \& Hairunnisah, 2017; Hashem et al., 2017; Medyawicesar, 2018; Rusdiyanto et al., 2019) menyatakan bahwa secara parsial non performing loan berpengaruh positif dan signifikan terhadap harga saham. Namun, terdapat hasil penelitian yang berbeda, yaitu penelitian yang dilakukan oleh (Adriana \& Perdana, 2018; Catriwati, 2017; Karla, 2014; Oraby, 2018) yang menyatakan bahwa secara parsial non performing loan tidak berpengaruh terhadap harga saham. Berdasarkan pemaparan tersebut, maka hipotesis alternatif kedua yang diajukan dalam penelitian ini adalah: $\mathrm{H}_{2}$ : Non Performing Loan (NPL) berpengaruh negatif dan signifikan terhadap harga saham.

Penelitian mengenai variabel capital adequacy ratio dilakukan oleh (Hajar et al., 2020; Nureny, 2020; Rusdiyanto et al., 2019; Satria \& Hatta, 2017) yang menyatakan bahwa secara parsial capital adequacy ratio berpengaruh positif dan signifikan terhadap harga saham. Penggunaan capital adequacy ratio yang tepat dapat mengoperasikan bank untuk menghasilkan keuntungan. Tingginya tingkat capital adequacy ratio akan mempengaruhi kualitas kinerja bank tersebut. Modal pada suatu bank sangat mempengaruhi tingkat kepercayaan masyarakat terhadap kinerja bank, sehingga capital adequacy ratio akan berpengaruh positif terhadap harga saham (Martanorika, 2018). Sementara hasil penelitian yang dilakukan oleh Warsiati (2019) menyatakan bahwa secara parsial capital adequacy ratio berpengaruh negatif dan signifikan terhadap harga saham. Namun, terdapat hasil penelitian yang berbeda, yaitu penelitian yang dilakukan oleh (Catriwati, 2017; Karla, 2014) yang menyatakan bahwa secara parsial capital adequacy ratio tidak berpengaruh terhadap harga saham. Berdasarkan pemaparan tersebut, maka hipotesis alternatif ketiga yang diajukan dalam penelitian ini adalah: $\mathrm{H}_{3}$ : Capital Adequacy Ratio (CAR) berpengaruh positif dan signifikan terhadap harga saham.

\section{METODE PENELITIAN}

Penelitian ini dilakukan dengan menggunakan metode deskriptif kuantitatif pada perusahaan bank umum konvensional yang terdaftar di Bursa Efek Indonesia periode 2015-2019. Data 
penelitian yang digunakan merupakan data sekunder yang kemudian diolah dan dianalisis di dalam aplikasi software SPSS 25. Data yang meliputi net interest margin, non performing loan, dan capital adequacy ratio diperoleh dari laporan keuangan tahunan selama lima tahun berturut-turut pada perusahaan perbankan konvensional melalui situs www.idx.co.id maupun situs resmi perbankan konvensional. Sementara data harga saham diperoleh dari situs www.investing.com Sampel penelitian ini dipilih secara purposive sampling dengan menggunakan kriteria pemilihan sampel yang telah ditetapkan oleh peneliti. Berdasarkan kriteria pemilihan sampel tersebut, terdapat 15 Bank Umum Konvensional yang terdaftar di BEI periode 2015-2019 dari total populasi secara keseluruhan sebanyak 42 perusahaan perbankan konvensional.

Adapun kriteria yang ditetapkan dalam pemilihan sampel pada penelitian ini adalah perusahaan bank umum konvensional yang terdaftar di BEI periode 2015-2019, perusahaan bank umum konvensional yang tidak menerbitkan laporan keuangan tahunan yang telah diaudit secara berturut-turut selama periode 2015-2019, perusahaan bank umum konvensional yang tidak memiliki kelengkapan data terkait variabel penelitian, dan perusahaan bank umum konvensional yang mengalami defisit selama periode 2015-2019.

Metode analisis data peneletian menggunakan regresi linear yang merupakan metode analisis yang dapat menjelaskan hubungan linear antara variabel dependen dengan dua atau lebih variabel independen. Terdapat model persamaan regresi yang digunakan untuk menjelaskan nilai suatu variabel dengan persamaan sebagai berikut:

$$
\mathrm{Y}=\alpha+\beta_{1} \mathrm{X}_{1}+\beta_{2} \mathrm{X}_{2}+\beta_{3} \mathrm{X}_{3}+\mathrm{e}
$$

Dimana:

\begin{tabular}{|c|c|}
\hline Y & $=$ variabel dependen (harga saham) \\
\hline$\alpha$ & $=$ nilai konstan \\
\hline$\beta_{1}, \beta_{2}, \beta_{3}$ & $=$ nilai koefisien regresi \\
\hline $\mathrm{X}_{1}$ & $=$ variabel independen $(\mathrm{NIM})$ \\
\hline $\mathrm{X}_{2}$ & $=$ variabel independen $(\mathrm{NPL})$ \\
\hline$X_{3}$ & $=$ variabel independen $(\mathrm{CAR})$ \\
\hline e & $=$ error term \\
\hline
\end{tabular}

\section{HASIL DAN PEMBAHASAN}

Penggunaan analisis statistik deskriptif bertujuan untuk merepresentasikan gambaran mengenai variabel-variabel di dalam suatu penelitian secara statistik seperti nilai rata-rata, nilai standar deviasi, nilai maksimum, dan nilai minimum. Nilai rata-rata digunakan untuk menjelaskan seluruh data kelompok dengan dasar rata-rata dari data tersebut. Nilai maksimum dan minimum digunakan untuk mengetahui nilai ekstrem atau relatif pada data kelompok yang bersangkutan berdasarkan pada jumlah terkecil dan terbesar.

Variabel dependen harga saham memiliki rata-rata (mean) sebesar 4.237,17, harga terendah sebesar 84,00, dan harga tertinggi sebesar 33.425. Pada variabel independen NIM menunjukkan hasil rata-rata (mean) sebesar 5,8344, rasio terendah sebesar 1,07, dan rasio tertinggi sebesar 12,00. Pada variabel NPL menunjukkan hasil rata-rata (mean) sebesar 2,6452, rasio terendah sebesar 0,70, dan rasio tertinggi sebesar 6,77. Pada variabel CAR menunjukkan hasil rata-rata (mean) sebesar 20,2491, rasio terendah sebesar 12,97, dan rasio tertinggi sebesar 26,21. 
Tabel 1.

Hasil Analisis Statistik Deskriptif

\begin{tabular}{lccccc}
\hline Variabel & N & Minimum & Maksimum & Mean & Std.Deviation \\
\hline Harga Saham & 75 & 84 & 33425 & 4237,17 & 5717,575 \\
NIM & 75 & 1,07 & 12,00 & 5,8344 & 2,11493 \\
NPL & 75 & 0,70 & 6,77 & 2,6452 & 1,14247 \\
CAR & 75 & 12,97 & 26,21 & 20,2491 & 2,99895 \\
\hline
\end{tabular}

Sumber: Data diolah, 2020

Diketahui nilai standar deviasi variabel CAR lebih besar dari nilai standar deviasi yang dimiliki oleh variabel NIM dan NPL. Hal ini menunjukkan bahwa semakin besar standar deviasi yang dimiliki, maka semakin beragam atau bervariasi data yang digunakan.

Pengujian asumsi klasik dilakukan guna mengetahui kondisi data di dalam penelitian agar dapat menentukan model analisis data yang sesuai untuk digunakan. Pada penelitian ini, uji asumsi klasik yang digunakan peneliti terdiri dari uji normalitas, uji multikolinearitas, uji hetersokedastisitas, dan uji autokorelasi. Uji normalitas bertujuan untuk menguji apakah data yang digunakan dalam penelitian berdistribusi secara normal atau tidak. Penelitian ini menggunakan uji One-Sample Kolmogorov-Sminov dengan taraf signifikansi $5 \%$ atau memiliki nilai profitabilitas (sig) $>0,05$.

Tabel 2.

Hasil Uji Normalitas Data

\begin{tabular}{lcc}
\hline Variabel & Nilai Profitabilitas & Interpretasi \\
\hline Harga Saham & 0,000 & Tidak terdistribusi normal \\
NIM & 0,002 & Tidak terdistribusi normal \\
NPL & 0,051 & Terdistribusi normal \\
CAR & 0,200 & Terdistribusi normal \\
Unstandardized Residual & 0,000 & Tidak terdistribusi normal \\
\hline
\end{tabular}

Sumber: Data diolah, 2020

Harga saham dan NIM tidak terdistribusi secara normal dikarenakan nilai profitabilitas < 0,05, sedangkan NPL dan CAR sudah terdistribusi secara normal dikarenakan nilai profitabilitas > 0,05. Namun, normal atau tidaknya suatu data secara keseluruhan dapat dilihat dari nilai profitabilitas unstandardized residual. Pada tabel di atas menujukkan bahwa unstandardized residual memiliki nilai profitabilitas < 0,05 maka dapat disimpulkan bahwa data tersebut tidak layak untuk dilakukannya regresi linear karena melanggar uji asumsi klasik, sehingga variabel-variabel tersebut harus ditransformasi agar data terdistribusi secara normal. Transformsi data menggunakan bentuk logaritma natural (Ln) sehingga didapat persamaan regresi sebagai berikut: 
Ln Harga Saham $=\alpha+\beta_{1} \mathrm{NIM}_{\mathrm{it}}+\beta_{2} \mathrm{NPL}_{\mathrm{it}}+\beta_{3} \mathrm{CAR}_{\mathrm{it}}+\mathrm{e}$

Tabel 3.

Hasil Uji Normalitas Data Setelah Transformasi Data

\begin{tabular}{lcc}
\hline Variabel & Nilai Profitabilitas & Interpretasi \\
\hline LN Harga Saham & 0,053 & Terdistribusi normal \\
NIM & 0,002 & Tidak terdistribusi normal \\
NPL & 0,051 & Terdistribusi normal \\
CAR & 0,200 & Terdistribusi normal \\
Unstandardized Residual & 0,200 & Terdistribusi normal \\
\hline
\end{tabular}

Sumber: Data diolah, 2020

Pengujian normalitas setelah dilakukan transformasi data, data tersebut terdistribusi secara normal. Hal ini dapat dilihat dari nilai profitabilitas pada unstandardized residual. Pada tabel di atas menujukkan bahwa unstandardized residual memiliki nilai profitabilitas > 0,05 maka dapat disimpulkan bahwa data tersebut layak untuk dilakukannya regresi linear.

Uji asumsi klasik yang digunakan setelah uji normalitas adalah uji multikolinearitas. Uji multikolinearitas berguna untuk mengetahui ada tidaknya korelasi atau hubungan linear antarvariabel independen dengan menggunakan model regresi. Apabila terjadi korelasi pada variabel independen, maka hubungan antara variabel independen dan variabel dependen akan menjadi terganggu. Model regresi yang baik tidak terjadi korelasi diantara variabel independen (Ghozali, 2018).

Tabel 4.

Hasil Uji Multikolinearitas

\begin{tabular}{lccc}
\hline Variabel & VIF & Nilai Tolerance & Asumsi Multikolinearitas \\
\hline NIM & 1,588 & 0,630 & Tidak terjadi multikolinearitas \\
NPL & 1,535 & 0,651 & Tidak terjadi multikolinearitas \\
CAR & 1,328 & 0,753 & Tidak terjadi multikolinearitas
\end{tabular}

Sumber: Data diolah, 2020

Pengujian multikolinearitas untuk semua variabel independen dalam penelitian ini adalah tidak terjadi multikolinearitas. Hasil ini didasarkan pada angka nilai tolerance yang lebih besar dari atau sama dengan 0,1 dan Variance Inflation Factor (VIF) kurang dari atau sama dengan 10. Variabel NIM memiliki nilai tolerance sebesar 0,630, NPL memiliki nilai tolerance sebesar 0,651, dan CAR 
memiliki nilai tolerance sebesar 0,753 . Sementara itu, VIF untuk variabel NIM sebesar 1,588 , NPL sebesar 1,535, dan CAR sebesar 1,328.

Uji heteroskedastisitas digunakan untuk mengetahui ada tidaknya ketidaksamaan varian dari residual untuk seluruh pengamatan atas variabel independen (Ghozali, 2018). Pada penelitian ini, uji heteroskedastisitas menggunakan langkah uji glejser dengan nilai signifikansi sebesar 0,05 .

Tabel 5.

Hasil Uji Glejser

\begin{tabular}{lcl}
\hline Variabel & Sig. & Asumsi Heteroskedastisitas \\
\hline NIM & 0,162 & Tidak terjadi heteroskedastisitas \\
NPL & 0,876 & Tidak terjadi heteroskedastisitas \\
CAR & 0,783 & Tidak terjadi heteroskedastisitas
\end{tabular}

Sumber: Data diolah, 2020

Hasil uji glejser, menunjukkan bahwa nilai signifikansi (p-value) seluruh variabel independen, yaitu NIM $(0,162)$, NPL $(0,876)$, dan CAR $(0,783)$ lebih dari 0,05 sehingga dapat disimpulkan bahwa model regresi dalam penelitian ini tidak terjadi heteroskedastisitas.

Pengujian terakhir dalam uji asumsi klasik adalah uji autokorelasi. Uji autokorelasi digunakan untuk mengetahui ada tidaknya korelasi antara kesalahan penganggu pada periode $\mathrm{t}$ terhadap periode t-1 (Ghozali, 2018). Pada penelitian ini peneliti menggunakan metode Durbin Watson yang diperoleh dari nilai $\mathrm{DW}_{\text {hitung }}$ dan $\mathrm{DW}_{\text {tabel }}(\mathrm{dL}$ dan $\mathrm{dU}$ ). Syarat agar tidak terjadinya gejala autokorelasi adalah nilai DW harus lebih besar dari nilai dU dan harus lebih kecil dari $4-\mathrm{dU}$.

Tabel 6.

\section{Hasil Uji Autokorelasi}

\begin{tabular}{|c|c|c|c|}
\hline \multicolumn{2}{|c|}{ DW $W_{\text {tabel }}$} & \multirow{2}{*}{ DW ${ }_{\text {hitung }}$} & \multirow{2}{*}{ Asumsi Autokorelasi } \\
\hline Dl & Du & & \\
\hline 1,5432 & 1,7092 & 0,400 & Terjadi gejala autokorelasi \\
\hline
\end{tabular}

Sumber: Data diolah, 2020

Nilai dL dan dU diperoleh dari tabel durbin watson untuk jumlah observasi $(\mathrm{n}=75)$ dan jumlah variabel bebas yang digunakan dalam penelitian ini (k-3) maka nilai $\mathrm{dL}$ sebesar 1,5432 dan nilai dU sebesar 1,7092. Hasil pengujian autokorelasi menunjukkan nilai durbin watson sebesar 0,400 maka dapat diketahui bahwa nilai tersebut tidak memenuhi persyaratan pengujian autokorelasi, yaitu $1,7092<0,400<4-1,7092$. Atas dasar hasil pengujian tersebut dapat dinyatakan bahwa terjadi gejala autokorelasi. Dalam mengatasi terjadinya gejala autokorelasi maka diperlukan perbaikan. Perbaikan 
autokorelasi dapat dilihat dari nilai rho $(\rho)$ yang dapat diestimasi dengan beberapa cara. Metode yang digunakan dalam penelitian ini adalah metode Cochrane-Orcutt (C-O). Nilai rho ( $\rho$ ) didapatkan dengan menggunakan rumus LAG(RES_4), setelah diketahui nilai rho ( $\rho$ ) sebesar 0,813 maka satuan nilai tersebut yang akan digunakan untuk mentransformasi seluruh variabel penelitian dengan rumus $\mathrm{LAG}=$ variabel $-(0,813 \times \mathrm{LAG}($ variabel $))$. Hasilnya dari transformasi tersebut kemudian dilakukan regresi kembali dan hasil regresi diasumsikan sudah tidak terjadi adanya autokorelasi.

Hasil pengujian autokorelasi dengan menggunakan uji cochrane-orcutt (c-o) menunjukkan nilai durbin watson sebesar 1,722 maka dapat diketahui bahwa nilai tersebut telah memenuhi persyaratan pengujian autokorelasi, yaitu $1,7092<1,722<4-1,7092$. Atas dasar hasil pengujian tersebut dapat dinyatakan bahwa tidak terjadi autokorelasi. Dengan demikian metode cochrane-orcutt (c-o) dapat memperbaiki masalah terjadinya gejala autokorelasi.

Tabel 7.

Hasil Uji Cochrane-Orcutt (C-O)

\begin{tabular}{ccccc}
\hline \multicolumn{2}{c}{ DW $_{\text {tabel }}$} & & & DW $_{\text {hitung }}$ \\
Dl & Du & & & Asumsi Autokorelasi \\
\cline { 1 - 2 } 1,5432 & 1,7092 & & 1,722 & Tidak terjadi autokorelasi \\
\hline
\end{tabular}

Sumber: Data diolah, 2020

Pada penelitian ini, penggunaan analisis regresi linear sederhana digunakan untuk menguji hipotesis pertama, kedua, dan ketiga dilakukan dengan menggunakan metode regresi linear sederhana.

Tabel 8.

Hasil Uji Regresi Linear Sederhana

\begin{tabular}{ccccccc}
\hline $\begin{array}{c}\text { Model } \\
\text { Regresi }\end{array}$ & $\mathbf{r}^{2}$ & Sig. & Konstanta & Koefisien & $\mathbf{t}_{\text {hitung }}$ & $\mathbf{t}_{\text {tabel }}$ \\
\hline $\mathrm{X}_{1}-\mathrm{Y}$ & 0,212 & 0,000 & 5,962 & 0,288 & 4,431 & 1,99394 \\
$\mathrm{X}_{2}-\mathrm{Y}$ & 0,158 & 0,000 & 8,856 & $-0,460$ & $-3,700$ & 1,99394 \\
$\mathrm{X}_{3}-\mathrm{Y}$ & 0,068 & 0,024 & 5,315 & 0,115 & 2,306 & 1,99394 \\
\hline
\end{tabular}

Sumber: Data diolah, 2020

Hasil analisis variabel net interest margin berpengaruh positif dan signifikan terhadap harga saham pada Bank Umum Konvensional yang terdaftar di Bursa Efek Indonesia pada tahun 2015-2019. Hal ini dapat diketahui dari hasil koefisien regresi $\mathrm{X}_{1}$ sebesar 0,288 dan nilai signifikansi $\mathrm{X}_{1}$ pada uji tersebut lebih kecil dari 0,05 yaitu sebesar 0,000. Hasil tersebut menunjukkan bahwa setiap kenaikan net interest margin sebesar satu, maka harga saham akan meningkat secara signifikan sebesar 0,288 dengan asumsi variabel lain konstan. Sementara, nilai koefisien determinasi $\left(\mathrm{r}^{2}\right)$ sebesar 0,212 menunjukkan bahwa net interest margin berpengaruh sebesar $21,2 \%$ terhadap harga saham,

Pengaruh Net Interest Margin, Non Performing Loan dan Capital Adequacy Ratio Terhadap Harga Saham Sayid Aulia Taslim dan Gusganda Suria Manda 
sedangkan sisanya sebesar 78,8\% dipengaruhi oleh variabel lain yang tidak diteliti di dalam penelitian ini. Nilai $t_{\text {hitung }}$ sebesar 4,431 dan nilai $t_{\text {tabel }}$ sebesar 1,99394 sehingga diperoleh $t_{\text {hitung }}>t_{\text {tabel }}$. Hal ini menunjukkan bahwa hasil pengujian net interest margin $\left(\mathrm{X}_{1}\right)$ berpengaruh signifikan terhadap harga saham (Y).

Hasil penelitian ini konsisten dengan hasil penelitian yang dilakukan oleh (Catriwati, 2017; Larasati et al., 2017; Wulansari \& Prihantoro, 2018) yang menyatakan bahwa secara parsial net interest margin berpengaruh positif dan signifikan terhadap harga saham. Hasil ini dapat diartikan bahwa semakin tingginya net interest margin maka akan terjadi kenaikan pada harga saham. Informasi net interest margin dapat memberikan sinyal kepada para investor dalam pengambilan keputusan dalam berinvestasi. Ini karena net interest margin yang tinggi di industri perbankan dapat menjadi referensi yang menggiurkan bagi bank karena net interest margin merupakan sumber pendapatan bank. Oleh karena itu, sangat wajar jika net interest margin akan mempengaruhi laba bank dan harga saham. Semakin tinggi net interest margin maka semakin besar laba yang diperoleh sehingga akan mempengaruhi profitabilitas bank dan akan berdampak positif kepada harga saham.

Hasil analisis variabel non performing loan berpengaruh negatif dan signifikan terhadap harga saham pada Bank Umum Konvensional yang terdaftar di Bursa Efek Indonesia pada tahun 2015-2019. Hal ini dapat diketahui dari hasil koefisien regresi $X_{2}$ sebesar -0,460 dan nilai signifikansi $\mathrm{X}_{2}$ pada uji tersebut lebih kecil dari 0,05 yaitu sebesar 0,000. Hasil tersebut menunjukkan bahwa setiap kenaikan non performing loan sebesar satu, maka harga saham akan menurun secara signifikan sebesar -0,460 dengan asumsi variabel lain konstan. Sementara, nilai koefisien determinasi $\left(\mathrm{r}^{2}\right)$ sebesar 0,158 menunjukkan bahwa non performing loan berpengaruh sebesar $15,8 \%$ terhadap harga saham, sedangkan sisanya sebesar $84,2 \%$ dipengaruhi oleh variabel lain yang tidak diteliti di dalam penelitian ini. Nilai $t_{\text {hitung }}$ sebesar $-3,700$ dan nilai $t_{\text {tabel }}$ sebesar 1,99394 sehingga diperoleh $t_{\text {hitung }}>t_{\text {tabel }}$. Hal ini menunjukkan bahwa hasil pengujian non performing loan $\left(\mathrm{X}_{2}\right)$ berpengaruh signifikan terhadap harga saham (Y).

Hasil penelitian ini konsisten dengan hasil penelitian yang dilakukan oleh (Buchory, 2020; Martanorika, 2018) yang menyatakan bahwa secara parsial non performing loan berpengaruh negatif dan signifikan terhadap harga saham. Hasil ini dapat diartikan bahwa semakin tingginya non performing loan maka akan terjadi penurunan pada harga saham sehingga hasil tersebut dapat menjadi informasi bagi para investor yang ingin menanamkan modalnya di pasar modal. Tekanan yang tinggi pada non performing loan akan meningkatkan risiko sistem perbankan. Rasio non performing loan yang tinggi akan meningkatkan biaya, baik biaya cadangan aset produktif ataupun biaya lainnya. Hal tersebut akan merusak kinerja bank dan akan berdampak pada harga saham Bank Umum Konvensional yang terdaftar di BEI.

Dapat diketahui hasil analisis variabel capital adequacy ratio berpengaruh positif dan signifikan terhadap harga saham pada Bank Umum Konvensional yang terdaftar di Bursa Efek Indonesia pada tahun 2015-2019. Hal ini dapat diketahui dari hasil koefisien regresi $\mathrm{X}_{3}$ sebesar 0,115 dan nilai signifikansi $X_{3}$ pada uji tersebut lebih kecil dari 0,05 yaitu sebesar 0,024. Hasil tersebut menunjukkan bahwa setiap kenaikan capital adequacy ratio sebesar satu, maka harga saham akan meningkat secara signifikan sebesar 0,024 dengan asumsi variabel lain konstan. Sementara, nilai koefisien determinasi $\left(\mathrm{r}^{2}\right)$ sebesar 0,068 menunjukkan bahwa capital adequacy ratio berpengaruh sebesar 6,8\% terhadap harga saham, sedangkan sisanya sebesar 93,2\% dipengaruhi oleh variabel lain yang tidak diteliti di dalam penelitian ini. Nilai $t_{\text {hitung }}$ sebesar 2,306 dan nilai $t_{\text {tabel }}$ sebesar 1,99394 sehingga diperoleh $t_{\text {hitung }}>t_{\text {tabell }}$. Hal ini menunjukkan bahwa hasil pengujian capital adequacy ratio $\left(\mathrm{X}_{3}\right)$ berpengaruh signifikan terhadap harga saham $(\mathrm{Y})$.

Pengaruh Net Interest Margin, Non Performing Loan dan Capital Adequacy Ratio Terhadap Harga Saham Sayid Aulia Taslim dan Gusganda Suria Manda 
Hasil penelitian ini konsisten dengan hasil penelitian yang dilakukan oleh (Hajar et al., 2020; Nureny, 2020; Rusdiyanto et al., 2019; Satria \& Hatta, 2017) yang menyatakan bahwa secara parsial Capital Adequacy Ratio berpengaruh positif dan signifikan terhadap harga saham. Hasil ini dapat diartikan bahwa semakin tingginya Capital Adequacy Ratio maka akan terjadi kenaikan pada harga saham sehingga bank tersebut memiliki modal yang cukup untuk melakukan kegiatan usaha dan menanggung risiko jika bank tersebut dilikuidasi. Rasio yang tinggi pada Capital Adequacy Ratio akan mendorong para investor untuk melakukan investasi pada perusahaan perbankan tersebut. Hal ini dikarenakan Capital Adequacy Ratio yang merupakan representasi modal perusahaan memiliki hubungan positif pada harga saham. Ini berarti dengan jumlah Capital Adequacy Ratio yang tinggi maka modal yang dimiliki perusahan juga tinggi sehingga risiko dalam berinvestasi rendah.

Analisis regresi linear berganda digunakan untuk melihat ada atau tidaknya pengaruh secara simultan antara variabel independen dengan variabel dependen. Pada penelitian ini, metode analisis data yang digunakan adalah regresi linear berganda.

Tabel 9.

Hasil Uji Regresi Linear Berganda

\begin{tabular}{|c|c|c|c|}
\hline Variabel & Koefisien Regresi & $\mathbf{T}$ & Sig. \\
\hline Konstanta & 6,801 & 5,384 & 0,000 \\
\hline NIM & 0,212 & 2,602 & 0,011 \\
\hline NPL & $-0,229$ & $-1,544$ & 0,127 \\
\hline CAR & 0,010 & 0,196 & 0,845 \\
\hline \multicolumn{2}{|c|}{ Koefisien Determinasi (Adjusted $\mathrm{R}^{2}$ ) } & \multicolumn{2}{|c|}{0,209} \\
\hline $\mathrm{F}_{\text {hitung }}$ & & \multicolumn{2}{|c|}{7,507} \\
\hline $\mathrm{F}_{\text {tabel }}$ & & \multicolumn{2}{|c|}{2,73} \\
\hline Signifikansi F & & \multicolumn{2}{|c|}{0,000} \\
\hline
\end{tabular}

Sumber: Data diolah, 2020

Berdasarkan hasil pengujian regresi linear berganda pada Tabel 9, diperoleh persamaan yang mempengaruhi Harga Saham, yaitu:

Harga Saham $=6,801+0,212 \mathrm{NIM}-0,229 \mathrm{NPL}+0,010 \mathrm{CAR}$

Hasil analisis menunjukkan bahwa variabel net interest margin, non performing loan, dan capital adequacy ratio secara simultan berpengaruh positif dan signifikan terhadap harga saham pada Bank Umum Konvensional yang terdaftar di Bursa Efek Indonesia pada tahun 2015-2019. Hal ini dapat diketahui dari hasil nilai koefisien regresi NIM sebesar 0,212 yang artinya setiap pertambahan NIM satu satuan, maka harga saham akan meningkat sebesar 0,212 dengan asumsi nilai variabel independen lain tetap. Nilai koefisien regresi NPL menunjukkan hasil negatif yaitu sebesar -0,229 yang artinya setiap pertambahan NPL satu satuan, maka harga saham akan menurun sebesar 0,229 dengan asumsi nilai variabel independen lain tetap.

Pengaruh Net Interest Margin, Non Performing Loan dan Capital Adequacy Ratio Terhadap Harga Saham Sayid Aulia Taslim dan Gusganda Suria Manda 
Nilai koefisien regresi CAR sebesar 0,010 yang artinya setiap pertambahan CAR satu satuan, maka harga saham akan meningkat sebesar 0,010 dengan asumsi nilai variabel independen lain tetap. Sedangkan hasil nilai signifikansi $\mathrm{F}$ pada uji tersebut diperoleh sebesar 0,000. Hal ini menunjukkan bahwa 0,000 lebih kecil dari nilai profitabilitas yang telah ditentukan yakni 0,05 maka dapat disimpulkan bahwa Net Interest Margin (NIM), Non Performing Loan (NPL), dan Capital Adequacy Ratio (CAR) secara simultan berpengaruh signifikan terhadap harga saham.

Nilai koefisien determinasi (Adjusted $\mathrm{R}^{2}$ ) sebesar 0,209 yang menunjukkan bahwa sebesar 20,9\% harga saham dipengaruhi oleh variabel net interest margin, non performing loan, dan capital adequacy ratio, sedangkan sisanya sebesar $79,1 \%$ dipengaruhi oleh variabel lain yang tidak diteliti di dalam penelitian ini. Nilai $F_{\text {hitung }}$ sebesar 7,507 sementara nilai $F_{\text {tabel }}$ sebesar 2,73 sehingga diperoleh $\mathrm{F}_{\text {hitung }}>\mathrm{F}_{\text {tabel. }}$. Hal ini menunjukkan bahwa hasil pengujian net interest margin $\left(\mathrm{X}_{1}\right)$, non performing loan $\left(\mathrm{X}_{2}\right)$, dan capital adequacy ratio $\left(\mathrm{X}_{3}\right)$ berpengaruh positif dan signifikan terhadap harga saham (Y).

\section{SIMPULAN DAN SARAN}

Berdasarkan hasil analisis data, pengujian hipotesis, dan pembahasan yang telah diuraikan, dapat ditarik beberapa kesimpulan terkait penelitian ini. Hasil menunjukkan bahwa net interest margin dan capital adequacy ratio secara parsial berpengaruh positif terhadap harga saham bank. Sementara itu, non performing loan secara parsial berpengaruh negatif terhadap harga saham bank. Secara simultan net interest margin, non performing loan, dan capital adequacy ratio memiliki pengaruh signifikan terhadap harga saham sebesar $20,9 \%$ dan sisanya $79,1 \%$ dipengaruhi variabel lain yang tidak diteliti atau variabel pengganggu.

Berdasarkan hasil penelitian dan kesimpulan yang telah diuraikan, maka saran yang dapat diberikan bagi manajemen perusahaan diharapkan agar senantiasa menjaga kualitas aktiva produktif, kepercayaan masyarakat, dan tingkat modalnya guna meningkatkan harga saham. Harga saham yang meningkat akan menarik investor dalam menanamkan modalnya. Bagi investor agar senantiasa memahami rasio keuangan yang mempengaruhi harga saham sebagai bahan dalam berinvestasi agar terhindar dari risiko kerugian dalam berinvestasi. Bagi peneliti selanjutnya diharapkan untuk menambah variabel penelitian lain atau memperluas ruang lingkup penelitian agar mendapatkan hasil yang lebih bervariasi dan mengetahui variabel-variabel apa saja yang dapat mempengaruhi harga saham seperti tingkat suku bunga, inflasi, nilai tukar valuta asing, sentimen pasar, dan lain-lain. Dan juga diharapkan memperpanjang periode penelitian untuk memperoleh sampel yang lebih representatif, sehingga akan menghasilkan uji statistik yang lebih baik mengenai pengaruh rasio keuangan terhadap harga saham.

\section{REFERENSI}

Adriana, C. H., \& Perdana, M. K. (2018). Factors Influencing the Stock Price of Banking Companies in the Indonesia Stock Exchange. Journal of Accounting and Strategic Finance, 1(1), 57-68. https://doi.org/10.33005/jasf.v1i01.26

Bank Indonesia. (2004). Surat Edaran Bank Indonesia No.6/23/DPNP Tahun 2004 Tentang Sistem Penilaian Tingkat Kesehatan Bank Umum.

Buchory, H. A. (2020). Banking Intermediation, Asset Quality, Price Earning Ratio and Stock Prices and Their Impact on Corporate Value-Study at the Regional Development Bank of West Java and Banten Provinces in Indonesia. International Journal of Innovation, Creativity and Change, 11(12), 513-527. 
Cahyani, N. P. D. W., \& Putri, I. A. . A. D. (2018). Pengaruh Risk Profile, Good Corporate Governance, Earnings dan Capital pada Perubahan Harga Saham Bank. E-Jurnal Akuntansi, 25(2), 959-987. https://doi.org/10.24843/eja.2018.v25.i02.p06

Catriwati. (2017). Pengaruh Capital Adequacy Ratio (CAR), Return On Asset (ROA), Loan To Deposit Ratio (LDR), Net Interest Margin (NIM), Non Performing Loan (NPL) dan Asset Growth terhadap Harga Saham Perbankan yang Terdaftar di Bursa Efek Indonesia. Jurnal Intra-Tech, 1(2), 76-91. http://journal.amikmahaputra.ac.id/index.php/JIT/article/view/14

Diyanti, A., \& Widyarti, E. T. (2012). Analisis Pengaruh Faktor Internal dan Eksternal Terhadap Terjadinya Non Performing Loan. Diponegoro Journal of Management, 1(2), 290-299.

Ghozali, I. (2018). Aplikasi Analisis Multivariate dengan Program IBM SPSS 25 (ke-9th ed.). Semarang: Badan Penerbit Universitas Diponegoro. (Edisi 9). Semarang: Badan Penerbit Universitas Diponegoro.

Hajar, N., Tho'in, M., \& Musta'an. (2020). The Effect of Banking Financial Soundness on Stock Prices to Earnings and Capital Variables. 4(4), 1099-1104.

Harahap, D. A., \& Hairunnisah, A. I. (2017). Pengaruh NPL, LDR, GCG, NIM , ROA, ROE, CAR, BOPO terhadap Harga Saham pada Perusahaan Perbankan yang Terdaftar di Bursa Efek Indonesia Dari Tahun 2010 - 2014. Jurnal Dimensi, 6(1), 22-40. https://doi.org/10.33373/dms.v6i1.522

Hashem, F. N. R., Alduneibat, K. A. A., \& Altawalbeh, M. A. F. (2017). The Impacts of Non-Performing Loans upon the Prices of Stocks in Jordanian Commercial Banks. Accounting and Finance Research, 6(1), 139147. https://doi.org/10.5430/afr.v6n1p139

Hendrayana, P., \& Yasa, G. (2015). Pengaruh Komponen RGEC pada Perubahan Harga Saham Perusahaan Perbankan di Bursa Efek Indonesia. E-Jurnal Akuntansi.

Infobanknews. (2016). OJK Tak Batasi NIM. Www.Infobanknews.Com. https://infobanknews.com/headline/ojktak-batasi-nim/

Karla, E. (2014). Analisis Pengaruh Capital Adequacy Ratio, Non Performing Loan, Return on Assets, Net Interest Margin dan Loan to Deposit Ratio pada PT Bank Central Asia, Tbk terhadap Harga Saham. $8(04), 1-14$.

Larasati, R., Isynuwardhana, D., \& Muslih, M. (2017). Analisis Pengaruh Non Performing Loan dan Net Interest Margin terhadap Harga Saham pada 5 Bank Umum Konvensional Penyalur Kredit Terbesar DI Indonesia Tahun 2010-2015. E-Proceeding of Management, 4(1), 402-410.

Martanorika, N. (2018). Pengaruh Loan to Deposit Ratio (LDR), Non Performing Loan (NPL), Capital Adequacy Ratio (CAR), Net Interest Margin (NIM) terhadap Harga Saham Bank Umum Konvensional yang Terdaftar di Bursa Efek Indonesia pada Tahun 2014-2016. Accounting \& Finance, 1(1), 1-15.

Medyawicesar, H. (2018). Analisis Komponen Tingkat Kesehatan Bank terhadap Harga Saham Bank Umum Swasta Nasional Devisa Yang Terdaftar Di Bursa Efek Indonesia Periode 2012-2016. 3(1), 21-31.

Nureny, N. (2020). Financial Performance and Share Prices of Banks of State-Owned Enterprises in Indonesia. Jurnal Ilmiah Ilmu Administrasi Publik, 9(2), 315-326. https://doi.org/10.26858/jiap.v9i2.12335

Oraby, D. S. A. (2018). The Credit Quality and the Market- Based Performance of Banks: A Comparative Study. International Journal of Accounting and Taxation, 6(1), 74-81. https://doi.org/10.15640/ijat.v6n1a6

Otoritas Jasa Keuangan. (2016). Peraturan OJK No.11/PJOK.03 tahun 2016 tentang Kewajiban Penyediaan Modal Minimum Bank Umum.

Puspitasari, D. (2009). Analisis Pengaruh CAR, NPL, PDN, NIM, BOPO, LDR dan Suku Bunga SBI Terhadap ROA (Studi Pada Bank Devisa di Indonesia Perioda 2003-2007). Universitas Diponegoro Semarang.

Rusdiyanto, R., Soetedjo, S., Susetyorini, S., \& Elan, U. (2019). The Effect of Capital Adequacy Ratio (CAR), Non Performing Loan (NPL), Operational Efficiency (BOPO), Net Interest Margin (NIM), and Loan to Deposit Ratio (LDR), on Return on Assets (ROA). Research Journal of Finance and Accounting, 8(7), 1499-1510. https://doi.org/10.7176/rjfa/10-10-19

Satria, I., \& Hatta, I. H. (2017). Pengaruh Kinerja Keuangan terhadap Harga Saham 10 Bank Terkemuka di Indonesia. Jurnal Akuntansi, 19(2), 179-191. https://doi.org/10.24912/ja.v19i2.93

Setyawan, A. W., \& Mawardi, W. (2012). Pengaruh Komponen Risik Based Bank Rating terhadap Harga Saham Perusahaan Perbankan yang Go Public di Bursa Efek Indonesia (BEI) Tahun 2008-2011. Diponegoro Business Review.

Takarini, N., \& Hendrarini, H. (2011). Rasio Keuangan dan Pengaruhnya Terhadap Harga Saham. Journal of Business and Banking, 1(2), 93-104.

Warsiati, W. (2019). Pengaruh Capital Adequacy Ratio (CAR) terhadap Harga Saham di Perusahaan Perbankan yang Terdaftar di Bursa Efek Indonesia Periode 2008-2017.

Winarsih, W. (2016). Analisis Tingkat Kesehatan Bank Berdasarkan Risk-Based Bank Rating Dan Pengaruhnya Terhadap Harga Saham. Jurnal Akuntansi Indonesia, 3(1), 71-80. https://doi.org/10.30659/jai.3.1.71-80

Pengaruh Net Interest Margin, Non Performing Loan dan Capital Adequacy Ratio Terhadap Harga Saham Sayid Aulia Taslim dan Gusganda Suria Manda 
Wulansari, D., \& Prihantoro, P. (2018). Pengaruh Kinerja Keuangan Terhadap Harga Saham yang Terdaftar di Bursa Efek Indonesia. Journal of Business Economics, 23(1), 1-18. https://doi.org/10.35760/eb.2018.v23i1.1815 